Bu makaleye atıfta bulunmak için/To cite this article:

OKUMUŞOĞLU, O. GEÇİKLİ, E. (2021). Fen Bilimleri Öğretmenlerinin Yeni Yaklaşım, Yöntem ve Teknikleri Bilme ve Kullanma Düzeyleri ile Mesleki Tükenmişlikleri. Atatürk Üniversitesi Sosyal Bilimler Enstitüsü Dergisi, 25 (Özel Sayı), 396-415.

\title{
Fen Bilimleri Öğretmenlerinin Yeni Yaklaşım, Yöntem ve Teknikleri Bilme ve Kullanma Düzeyleri ile Mesleki Tükenmişlikleri
}

\author{
Onur OKUMUSSOĞLU ${ }^{(*)}$ \\ Esra GEÇIKLI (**)
}

$\ddot{O}_{z:}$ Bu araştırmanın amacı, fen bilimleri öğretmenlerinin fen öğretimindeki yeni yaklaşım, yöntem ve teknikleri bilme ve kullanma düzeylerini ve mesleki tükenmişliklerini belirlemek ayrica aralarındaki iliş̧kiyi incelemektir. Bu araştırma ilişkisel tarama yönteminin kullanıldığı nicel bir araştırmadır ve Erzurum ili merkez ilçelerinde görev yapan toplam 200 fen bilimleri ögretmeni ile yürütülmüştür. Veri toplama aracı olarak fen ögretiminde Yeni Yaklaşım, Yöntem ve Teknikleri Bilme ve Kullanma Ölçeği ile Maslach Tükenmişlik Envanteri-Ĕ̆itimci Formu kullanılmıştır. Fen bilimleri ögretmenlerinin yeni yaklaşım, yöntem ve teknikleri ne düzeyde bildiği ve kullandı̆̆ betimsel istatistikler ile ortaya konulmaya çalışllmış, bilme ve kullanma düzeyleri arasındaki ilişki incelenmiştir. Ayrıca Maslach Tükenmişlik Envanteri-Eğitimci Formu ile fen bilimleri ögretmenlerinin duygusal tükenme, duyarsızlaşma ve kişisel başarı alt boyutlarında tükenmişlik düzeyleri araştırılmıs ve yeni yaklaşım, yöntem ve teknikleri bilme ve kullanma düzeyleri ile bu alt boyutlar arasındaki ilişki belirlenmeye çalışılmıştır. Araştırma sonucunda fen bilimleri ögretmenlerinin yeni yaklaşım, yöntem ve teknikleri orta düzeyde bildikleri ve kullandıklarl, ayrıca yeni yaklaşım, yöntem ve teknikleri bilme ve kullanma düzeyi arasında anlamlı ve pozitif bir ilişki olduğu belirlenmiştir. Fen bilimleri ögretmenlerinin duygusal tükenme, duyarsizlaşma ve kişisel başarı alt boyutlarında yüksek tükenmişlik düzeyinde oldukları tespit edilmiş fakat öğretmenlerin yeni yaklaşım, yöntem ve teknikleri bilme ve kullanma düzeyleri ile tükenmişlikleri arasında anlamlı bir ilişski olmadiğı görülmüş̧ür.

Anahtar Kelimeler: Yaklaşım, yöntem, teknik, tükenmişlik, fen eğitimi

\section{Science Teachers' Levels in Knowledge and Use of New Approaches, Methods and Techniques and Professional Burnout}

\begin{abstract}
This study is intended to detect the extent to which science teachers are familiar with new approaches, techniques and methods in science teaching, the extent to which they use these new approaches, techniques and methods, and the level of their occupational burnout as well as the relation between these three foci of the study. It is a quantitative study in which correlational survey model was used and was carried out with 200 science teachers working in central Erzurum. Scale of Familiarity with New Approaches, Methods and Techniques in Science Teaching and Maslach Burnout Inventory-Educator Survey were used as tools of data collection. In the study, the extent to which science teachers are familiar with and use new approaches, techniques and methods in science teaching was demonstrated through descriptive statistics, and the relation between the levels of teachers' familiarity with and use of new approaches, techniques and
\end{abstract}

\footnotetext{
*) Öğretmen, Milli Eğitim Bakanlığı, (e-posta: onurokumusoglu@gmail.com), (D) ORCID ID https://orcid.org/0000-0001-5739-6753

**) Dr. Öğr. Üyesi, Atatürk Üniversitesi Kazım Karabekir Eğitim Fakültesi Matematik ve Fen Bilimleri Eğitimi Bölümü, (e-posta: esra.gecikli@atauni.edu.tr), (D) ORCID ID. https://orcid.org/ 0000-0003-4402-2626

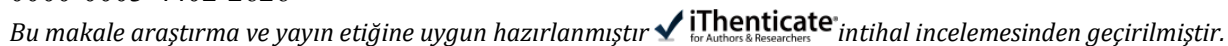


methods in science teaching was examined. In addition, science teachers' levels of occupational burnout were examined on the basis of such sub-dimensions as emotional burnout, desensitisation and individual success through Maslach Burnout Inventory-Educator Survey and the relation between teachers' levels of familiarity and use of new approaches, techniques and methods in science teaching, and these sub-dimensions was tried to be demonstrated. The findings show that science teachers are familiar with and use new approaches, techniques and methods in science teaching at medium level, and that there is a positive and significant relation between the level of familiarity with new approaches, techniques and methods in science teaching and the level of using them. It has been found out that science teachers are at high level of occupational burnout as far as such sub-dimensions as emotional burnout, desensitisation and individual success are concerned. According to the findings, there is not a significant relation between teachers' familiarity with and use of new approaches, techniques and methods in science teaching, and their level of occupational burnout.

Keywords: approach, method, technique, burnout, science teaching

Makale Gelis Tarihi: 05.02.2021

Makale Kabul Tarihi: 20.09.2021

DOI: 10.53487/ataunisosbil.875359

\section{Giriș}

21. yüz yılda tek bir tuşla istenilen bilgiye ulaşılabilmekte fakat ironik bir şekilde bilginin oluşum süresi edinilme süresinden çok daha hızlı olmaktadır. Dolayısıyla araştırma ve sorgulama yeteneği olan, bilgiye ulaşma yollarını bilen, edindiği bilgiler ile gündelik hayatı ilişkilendirebilen, bilimsel metodu hayatının bütününe entegre etmeyi başarmış, bir bilim insanı gözüyle dünyayı yorumlayabilen bireyler bu çağın insan profili haline dönüşmüştür. Bu süreçte eğitimin özellikle de fen eğitiminin payına da bu insan gücünün yetişmesini sağlamak düşmüştür (Eğitimi Araştırma ve Geliştirme Dairesi Başkanlığı [EARGED], 2011). Endüstri 4.0 dünyasında eğitim süreçlerinin değişmesi zorunlu hale gelmiş; artık klasik sıralarda oturan ve öğretmenini dinleyen öğrencilerin olduğu sınıflar yerini birlikte çalışmaya uygun masaların yer aldığı, zenginleştirilmiş ders içerikleri ve etkinliklerinin hâkim olduğu, güncel öğrenme yaklaşımlarının uygulandığı sınıflara bırakmak durumunda kalmıştır (Yarım ve Çelik, 2020).

Eğitim sürecinin hedefine ulaşmasında en önemli öğe hiç şüphesiz ki öğretmenlerdir. Yapılan çalışmalar öğretmen kalitesinin öğrenci başarısında ve öğrenme çıktılarında doğrudan etkili olduğunu göstermektedir (OECD, 2005a: 163; Williams ve Engel, 20122013). Değişen dünya düzeni şüphesiz ki öğretmenlerin de rolünü değiştirmiş, yaşam boyu öğrenen ve bunu öğrencilerine de öğretebilen, öğrencilerinin yaratıc1 düşünebilmesini sağlayabilmek adına kaynaklar sunup rehberlik edebilen, alan bilgi ve becerilerine hâkim, kendini güncelleyen öğretmenler çağı yakalamayı başarmışlardır (Aydeniz, 2017; Bozan, 2018; Erten, 2019). Öğretmenlerin derslerinde kullandıkları yöntem ve tekniklerin öğrencilerin bilgi, beceri ve tutumlarını etkileyen başlıca faktörlerden biri olduğu göz önüne alındığında yeni öğrenme yaklaşımlarından haberdar olmayan öğretmenlerin dijital yerli olarak ta isimlendirilen Z kuşağına etkili öğrenme ortamları sunması pek te mümkün gözükmemektedir (Pedro, 2006; Yarım ve Çelik, 2020). 
Fen Bilimleri Öğretmenlerinin Yeni Yaklaşım, Yöntem ve Teknikleri Bilme ve Kullanma Düzeyleri ile Mesleki Tükenmişlikleri

Alan yazın incelendiğinde öğretmenlerin sınıf ortamında kullanmayı tercih ettiği yöntem ve teknikleri araştıran çalışmaları görmek mümkündür (Aydede, Çağlayan, Matyar ve Gülnaz, 2006; Çelikkaya ve Kuş, 2009; Geçer ve Özel, 2012; Güneş, Dilek, Çelikoğlu ve Demir, 2011; Juuti, Lavonen, Uitto, Byman ve Meisalo, 2010; Mihladiz ve Duran, 2013; Önen, Mertoğlu, Saka ve Gürda, 2009; Soylu, 2009; Sözbilir, Şenocak ve Dilber, 2006; Şimşek ve Coşkun, 2012; Timur ve İmer, 2012; Yıldırım ve Demir, 2003.). Ancak bu araştırmalarda son yıllarda yaygınlaşan yaklaşım, yöntem ve tekniklerin yer almaması ve bu yaklaşım, yöntem veya tekniklerin bilinme ve kullanılma durumlarının ilişkilendirilmemiş oluşu eksiklik olarak göze çarpmaktadır.

Daha önce de değinildiği üzere öğretmenlik, özellikle son y1llarda beklentilerin oldukça yüksek olduğu bir meslek grubu haline gelmiştir. İdareciler, veliler ve öğrencilerin yanı sıra toplum da mesleklerinde daha bilgili ve etkili olmaları bakımından öğretmenlerin üzerinde giderek artan bir baskı oluşturmaktadır. Bu baskılar öğretmenlerin görevlerini tam olarak yerine getiremeyeceklerine dair bir inanç geliştirmelerine, strese girmelerine ve sonuç olarak mesleklerine dair ideallerini kaybetme, isteksizlik ve meslekten soğuma gibi sonuçlara neden olmaktadır (Çelikkaleli, 2011; Troman ve Woods, 2000). Bu durum tükenmişlik olarak isimlendirilmekte ve “duygusal tükenme, duyarsızlaşma ve kişisel başarı eksiliği” sendromlarıyla karakterize edilmektedir (Kokkinos, 2007; Maslach ve Jackson, 1981). Duygusal tükenme bireyin işinden dolayı kendisine fazla yüklenmesi ve tüketilmiş olma duygusunu, duyarsızlaşma duygudan yoksun olma ve tepki vermemeyi, kişisel başarı eksikliği ise kişinin kendini işine yetersiz ve başarısız olarak algılamasını ifade etmektedir (Durr, 2008; Gaines, 2011; Seferoğlu, Yıldız ve Yücel; 2014). Tükenmişliğin pek çok meslek grubunda görülebilmekle birlikte özellikle öğretmenler arasında yaygınlaştığı, yol açttğı fiziksel ve zihinsel yorgunluk nedeniyle öğretmenlerin mesleki performansları ve sınıf içi öğretme etkinliklerini olumsuz etkilediği alan yazında rapor edilmektedir (Hoyos ve Kallus, 2005; Maslach, Schaufe ve Leither, 2001; Durak ve Seferoğlu, 2017). Öğretmenlerde tükenmişliğe neden olan pek çok faktör tespit edilmekle birlikte en önemli nedenin öğretmenliğe yönelik yetkinlik inancı olması dikkat çekicidir (Betoret, 2009; Chan, 2007; Egyed ve Short, 2006; Karahan ve Uyanık Balat, 2011;). Öğretmen yetkinliği, öğretmenlerin eğitim-öğretim sürecinde hedeflerine ulaşmak adına gerekli olan etkinlikleri başarılı bir şekilde yapabileceklerine olan inancı olarak tanımlanmaktadır (Çelikkaleli, 2011). Tanımdan yola çıkılarak çağın gereksinimleri ile kendini geliştiren, alanındaki gelişmeleri takip eden, değişen öğrenci ihtiyaçları doğrultusunda yenilenen öğretmenlerin kendilerini daha yetkin görecekleri ve bununla paralel olarak ta tükenmişlik duygusuna kapılma ihtimallerinin azalacağı yönünde fikir geliştirmenin mümkün olduğu düşünülmüştür. Mevcut çalışma ile bu hipotez test edilmeye çalışılmıştır.

\section{Amaç}

$\mathrm{Bu}$ araştırmanın birinci amacı, fen bilimleri öğretmenlerinin fen öğretimindeki yeni yaklaşım, yöntem ve teknikleri bilme ve kullanma düzeylerini belirlemek, ayrıca bilme ve kullanma düzeyleri arasındaki ilişkiyi ortaya koymaktır. İkinci amacı ise fen bilimleri öğretmenlerinin mesleki tükenmişliklerini belirleyerek yeni yaklaşım, yöntem ve 
teknikleri bilme ve kullanma düzeyleri ile tükenmişlikleri arasında ilişki olup olmadığını gözler önüne sermektir. Bu amaçlar doğrultusunda aşağıdaki sorulara yanıt aranmıştır:

1. Fen bilimleri öğretmenlerinin yeni yaklaşım, yöntem ve teknikleri bilme ve kullanma düzeyleri nedir?

2. Fen bilimleri öğretmenlerinin yeni yaklaşım, yöntem ve teknikleri bilme ve kullanma düzeyleri arasında anlamlı bir ilişki var mıdır?

3. Fen bilimleri öğretmenlerinin mesleki tükenmişlikleri ne düzeydedir?

4. Fen bilimleri öğretmenlerinin mesleki tükenmişlik düzeyleri ile yeni yaklaşım, yöntem ve teknikleri bilme ve kullanma düzeyleri arasında anlamlı bir ilişki var midır?

\section{Yöntem}

\section{A. Araştırmanın Deseni}

Bu çalışma, fen bilimleri öğretmenlerinin yeni yaklaşım, yöntem ve teknikleri bilme ve kullanma düzeyleri ile mesleki tükenmişlikleri arasındaki ilişkiyi inceleyen ilişkisel tarama modelinde bir araştırmadır. İlişkisel tarama modeli iki veya daha fazla değişken arasında ilişkinin var olup olmadığını ve varsa büyüklük ve yönünü belirlemede kullanılan bir araştırma desenidir (Tekbıyık, 2014; Karasar, 2013: 52).

\section{B. Evren/Örneklem}

Bu araştırmada ulaşılabilir evreni Erzurum ilindeki tüm fen bilimleri öğretmenleridir. Çalışmanın örneklemi seçkisiz olmayan örnekleme yöntemlerinden uygun örnekleme yöntemi ile belirlenmiştir. Uygun örnekleme yöntemi, zaman ve işgücü açısından katılımcılara ulaşmanın zor olduğu durumlarda örneklemin kolay çalışılabilir gruplardan seçilmesidir (Büyüköztürk vd., 2017: 95). Bu yüzden çalışmanın örneklemi 2018-2019 eğitim yılında Erzurum ilinin merkez ilçelerinde bulunan okullarda görev yapan toplam 200 fen bilimleri öğretmeni olarak belirlenmiştir. Dış geçerliği sağlamak için araştırmanın örneklemi belirlenirken demografik özellikler açısından farklı öğretmenler çalışmaya dahil edilmiş ve örneklemin evreni yansıtmasına dikkat edilmiştir. Örneklemde yer alan katılımcılara ait demografik özellikler aşağıdaki tabloda verilmiş̧ir.

Tablo 1. Katılımcıların Demografik Özellikleri

\begin{tabular}{cccc}
\hline Değişken & Kategoriler & f & \% \\
\hline Cinsiyet & Erkek & 98 & 49 \\
& Kadın & 102 & 51 \\
\hline Mesleki Deneyim (yll) & $0-5$ & 52 & 26 \\
& $6-10$ & 68 & 34 \\
& $11-15$ & 38 & 19 \\
& 16 ve üzeri & 42 & 21 \\
\hline Görev Yapılan Okulun Sosyo- & İyi & 42 & 21 \\
Ekonomik Durumu & Orta & 96 & 48 \\
& Kötü & 62 & 31 \\
\hline
\end{tabular}


Fen Bilimleri Öğretmenlerinin Yeni Yaklașım, Yöntem ve Teknikleri Bilme ve Kullanma Düzeyleri ile Mesleki Tükenmişlikleri

\begin{tabular}{cccr}
\hline Yeni Öğrenme Yaklaşımları & Katıldım & 114 & 57 \\
$\begin{array}{c}\text { Konusunda Hizmet İçi Eğitime } \\
\text { Katılma Durumu }\end{array}$ & Katılmadım & 86 & 43 \\
\hline Görev Yapılan Okulda Fen & & & \\
Laboratuvarı Olma Durumu & Var & 120 & 60 \\
\hline Görev Yapılan Okulda İnternet & Yok & 80 & 40 \\
Altyapısı Durumu & Var & 178 & 89 \\
\hline & Yok & 22 & 11 \\
\hline & Toplam & 200 & 100 \\
\hline
\end{tabular}

Tablo incelendiğinde çalışmaya katılan öğretmenlerin \%51'inin kadın, \%49'unun erkek olduğu görülmektedir. Çalışmaya katılan öğretmenler çoğunlukla 6-10 yıl arası mesleki deneyime (\%34) sahiptir ve görev yaptığı okulun sosyoekonomik durumunu “orta" (\%48) olarak tanımlamaktadır. Ayrıca öğretmenlerin \%57'si öğrenme-öretme yaklaşımları ile ilgili en az bir hizmet içi eğitime katıldığını belirtmiştir. Katılımcıların \%60’1 görev yaptığı okulun fen laboratuvarı, \%89'u ise internet alt yapısının olduğunu belirtmiştir.

\section{Veri Toplama Araçları}

İlişsisel tarama yönteminin kullanıldığ Kişisel Bilgi Formu, Yeni Yaklaşım, Yöntem ve Teknikleri Bilme ve Kullanma Düzeyleri Ölçeği (YYYTBKDÖ) ile Maslach Tükenmişlik Envanteri-Eğitici Formu (MTE-EF) kullanılmıştır.

\section{Kişisel Bilgi Formu}

Kişisel Bilgi Formu, kişisel bilgilerin yer aldığı ve katılımcıların cinsiyet, mesleki deneyim, görev yapılan okulun sosyo-ekonomik durumu, yeni yaklaşım, yöntem ve tekniklerle ilgili hizmet içi eğitime katılma durumu, görev yapılan okulda fen laboratuvarı bulunma durumu gibi özellikleri belirlemeye yönelik sorulardan oluşmaktadır.

\section{Yeni Yaklaşım, Yöntem ve Teknikleri Bilme ve Kullanma Düzeyleri Ölçeği (YYYTBKDÖ)}

Bulut (2010) tarafından geliştirilerek fen bilimleri öğretmenlerine uygulanan Yeni Yaklaşım Yöntem ve Teknikleri Bilme ve Kullanma Düzeyleri Ölçeği yaklaşım, yöntem ve teknikler güncellenerek kullanılmıştır. Ölçeğin kapsam geçerliğini sağlayabilmek için fen öğretiminde ortaya çıkan yeni yaklaşım, yöntem ve teknikler alan yazın taraması yapılarak belirlenmiş, daha sonra üç alan uzmanı ve üç fen bilimleri öğretmeninin görüşü alınarak 23 yaklaşım, yöntem veya tekniğin ölçekte yer almasına karar verilmiştir. Ölçekte fen bilimleri öğretmenlerinden kendilerine sunulan bu 23 yaklaşım, yöntem veya tekniği bilme düzeylerini "hiç, az, orta, iyi veya çok iyi”" olarak, kullanma sıklıklarını ise "hiç, nadir, orta, sık, çok sık" olarak belirlemeleri istenmiştir. Maddeler, "Çok İyi” için beş, "İyi” için dört, "Orta” için üç, “Az" için iki ve "Hiç" için bir şeklinde kodlanmıştır. Ankette öğretmenlerin verdikleri cevapların puanları düzeylere göre sınıflandırılırken (n-1)/n (dizi genişliği/yapılacak grup sayısı) formülü kullanılmıştır (Tekin, 1993 akt. Ekici, Çıbık ve Fettahlıoğlu; 2014). Bir ile beş arasındaki her bir aralığın genişliği .8 
olarak hesaplanmıştır. Aralık genişliğinden yola çıkarak 1- 1.8 aralığı çok düşük düzeyi, 1.81-2.6 düşük düzeyi, 2.61-3.4 aralığı orta düzeyi, 3.41-4.2 aralı̆ğ yüksek düzeyi ve 4.21-5 aralığı ise çok yüksek düzeyi temsil etmektedir. Bulut (2010) çalışmasında ölçeğin Cronbach alpha değerini .90 olarak hesaplamıştır. Bu çalışmada öğretmenlerin fen öğretiminde yeni yaklaşım, yöntem ve teknikleri bilme düzeylerini belirleyen ifadelerin Cronbach alpha iç tutarlılık katsayısı .92, kullanma düzeylerini belirleyen ifadelerin Cronbach alpha iç tutarlılık katsayısı .85, tüm ifadelerin Cronbach alpha iç tutarlılık katsayısı ise .91 olarak hesaplanmıştır.

\section{Maslach Tükenmişlik Envanteri- Eğitimci Formu (MTE-EF)}

Fen bilimleri öğretmenlerinin mesleki tükenmişlik düzeylerini belirlemek amacıyla ilk olarak Maslach ve Jackson (1981) tarafindan geliştirilen ve İnce ve Şahin (2015) tarafindan Türkçeye uyarlanan Maslach Tükenmişlik Envanteri-Eğitimci Formu (MTEEF) kullanılmıştır. MTE-EF 22 ifadeden oluşmaktadır ve katılımcılardan her bir ifadeyi yaşama sıklı̆ı̆ını "her zaman, çoğu zaman, bazen, çok nadir, hiçbir zaman" şeklinde değerlendirmesi istenmiştir. MTE-EF; "duygusal tükenme", "duyarsızlaşma" ve "kişisel başarı" olmak üzere üç alt boyuttan oluşmaktadır. Duygusal tükenme alt boyutu 9 soru ile, duyarsızlaşma alt boyutu 5 soru ile ve kişisel başarı alt boyutu ise 8 soru ile ölçülmüsşür. Olumsuz sorulardan oluşan duygusal tükenme ve duyarsızlaşma alt boyutlarındaki puan artı̧̧ yüksek tükenmişlik düzeyini işaret ederken, kişisel başarı alt boyutundaki puan artışı düşük tükenmişlik düzeyini göstermektedir. MTE-EF aracıllı̆ 1 ile toplanan verilerin yorumu aşağıdaki puanlamaya göre yapılmıştır (Deran ve Beller, 2015: 80).

Tablo 2. MTE-EF Değerlendirme Tablosu

\begin{tabular}{clll}
\hline Alt Boyutlar & Düşük & Orta & Yüksek \\
\hline Duygusal Tükenme & $0-16$ & $17-26$ & 27 ve üzeri \\
Duyarsızlaşma & $0-6$ & $7-12$ & 13 ve üzeri \\
Kişisel başarı & 39 ve üzeri & $32-38$ & $0-31$ \\
\hline
\end{tabular}

\section{Verilerin Analizi}

Fen bilimleri öğretmenlerinin fen öğretiminde yeni yaklaşım, yöntem ve teknikleri bilme ve kullanma düzeyleri betimsel istatistikler aracılığı ile belirlenmiş̧tir. Fen bilimleri öğretmenlerinin yeni yaklaşım, yöntem ve teknikleri bilme ve kullanma düzeyleri arasındaki iliş̧i Pearson Momentler Çarpımı Korelasyon Analizi ile hesaplanmıştır.

Fen bilimleri öğretmenlerinin üç alt boyuttaki tükenmişlik düzeyleri yine betimsel istatistikler ile ortaya konulmuş, ayrıca fen bilimleri öğretmenlerinin mesleki tükenmişlik düzeyleri alt boyutları ile yeni yaklaşım, yöntem ve teknikleri bilme ve kullanma düzeyleri arasındaki ilişki ve bu ilişkilerin büyüklük ve yönleri Pearson Momentler Çarpımı Korelasyon Analizi kullanılarak belirlenmiştir. 
Fen Bilimleri Öğretmenlerinin Yeni Yaklaşım, Yöntem ve Teknikleri Bilme ve Kullanma Düzeyleri ile Mesleki Tükenmişlikleri

\section{Veri Seti ile Gerçekleştirilen Ön Analizler}

Fen bilimleri öğretmenlerinin YYYTBKDÖ ile MTE-EF alt boyutlarına ait veri setini için öncelikle kutu grafikleri oluşturularak uç değer olup olmadığ kontrol edilmiştir. Veri setimde yer alan 3 uç değer tespit edilerek bu veriler veri setinden çıkarılmıştır. Daha sonra veri setinin normal dağılımı incelenmiş, yapılan analiz sonucunda bilme ölçeği, kullanma ölçeği ve MTE-EF alt boyutları için çarpıklık ve basıklık değerleri hesaplanmıştır.

Tablo 3. Bilme Ölçeği, Kullanma Ölçeği ve Maslach Tükenmişlik Envanteri-Eğitimci Formu Alt Boyutları İçin Normal Dağılım Analiz Sonuçları

\begin{tabular}{cccccc}
\hline & & & \multicolumn{2}{c}{ Shapiro-Wilk } \\
\cline { 4 - 5 } & & \multicolumn{2}{c}{ Testi } \\
\cline { 4 - 6 } & Carpıklık & Basıklık & Istatistik & $\mathbf{p}$ \\
\hline YYYTBKDÖ-Bilme & 0.390 & -0.051 & 0.98 & 0.128 \\
YYYTBKDÖ-Kullanma & 0.269 & -0.118 & 0.98 & 0.144 \\
MTE-EF-Duygusal Tükenme Boyutu & 0.135 & -0.103 & 0.981 & 0.167 \\
MTE -EF-Duyarsılaşma Boyutu & 0.312 & -0.232 & 0.944 & 0.000 \\
MTE -EF- Kişisel Başarı Boyutu & -0.24 & 0.033 & 0.971 & 0.026 \\
\hline
\end{tabular}

Tablo 3 incelendiğinde YYYTBKDÖ ve MTE-EF alt boyutlarına ait çarpıklık ve basıklık değerlerinin \pm 1 aralığında olduğu yani normal dağılım gösterdiği görülmektedir (Tabachnick ve Fidell, 2007). Veri setinde yapılan Shapiro-Wilk testi sonuçlarının YYYTBKDÖ ve MTE-EF duygusal tükenme alt boyutunda normal dağılımı desteklerken( $p>05)$; MTE-EF duyarsızlaştırma ve kişisel başarı boyutlarında desteklemediği görülmektedir. Örneklemde yer alan katılımcı sayısının 20 ve üzerinde olduğu durumlarda parametrik testler için normallik varsayımının problem olmayacağ 1 (Tan, 2016, s.286) varsayımına dayanılarak analizlere veri seti ile devam edilmiştir.

\section{Bulgular}

Fen bilimleri öğretmenlerinin yeni yaklaşım, yöntem ve teknikleri bilme ve kullanma düzeylerine ilişkin bulgular Tablo 4 'te sunulmuştur.

Tablo 4. Fen Bilimleri Öğretmenlerinin Yeni Yaklaşım, Yöntem ve Teknikleri Bilme ve Kullanma Düzeylerine İlişkin Sonuçlar

\begin{tabular}{ccccc}
\hline & $\overline{\boldsymbol{X}}$ & ss & Min & Max \\
\hline Bilme Düzeyi & 3.12 & .67 & 1.74 & 4.91 \\
Kullanma Düzeyi & 2.69 & .68 & 1.43 & 4.57 \\
\hline
\end{tabular}

Tablo 4'e bakıldığında fen bilimleri öğretmeninin yeni yaklaşım, yöntem ve teknikleri bilme ortalamalarının 3.12, kullanma ortalamalarının ise 2.69 olduğu görülmektedir. $\mathrm{Bu}$ veriler bize fen bilimleri öğretmenlerinin yeni yaklaşım, yöntem ve teknikleri orta düzeyde bildiğini ve kullandığını göstermektedir. Fakat kullanma ortalamasının düşük düzeye çok yakın olduğu göz ardı edilmemelidir. Ortalamalar, fen bilimleri öğretmenlerinin yeni yaklaşım, yöntem ve teknikleri bilme düzeylerinin kullanma düzeylerinden yüksek olduğunu; fen bilimleri öğretmenlerinin bildikleri halde 
yeni yaklaşım, yöntem ve teknikleri uygulamadıkları veya uygulayamadıkları sonucunu vermektedir.

Fen bilimleri öğretmenlerinin her bir yeni yaklaşım, yöntem ve tekniği bilme düzeyi için betimsel analiz yapılmış ve bulgular Tablo 5 'te sunulmuştur.

Tablo 5. Fen Öğretiminde Yeni Yaklaşım, Yöntem ve Tekniklerin Fen Bilimleri Öğretmenleri Tarafindan Bilinme Düzeyleri

\begin{tabular}{cccc}
\hline Yaklaşım, Yöntem ve Teknikler & N & $\overline{\boldsymbol{X}}$ & Ss \\
\hline Etkinlik temelli & 200 & 4.21 & 0.84 \\
Sorgulamaya dayalı öğrenme & 200 & 4.18 & 0.91 \\
İşbirlikli öğrenme & 200 & 4.14 & 0.77 \\
Yaşam temelli öğrenme & 200 & 4.09 & 0.97 \\
Oyun tabanlı ögrenme & 200 & 4.00 & 0.85 \\
Altı şapkalı düşünme tekniği & 200 & 3.84 & 0.98 \\
Kavram karikatürü & 200 & 3.75 & 0.97 \\
Yansitıc Öğgrenme & 200 & 3.42 & 1.07 \\
Kişiselleştirilmiş öğrenme & 200 & 3.39 & 1.09 \\
Farklılaştırılmış öğretim modeli & 200 & 3.12 & 1.19 \\
Mobil öğrenme & 200 & 3.07 & 1.26 \\
Senaryo temelli & 200 & 2.99 & 1.18 \\
Sokratik sorgulama tekniği & 200 & 2.94 & 1.28 \\
Argümantasyon & 200 & 2.89 & 1.22 \\
Çevrimiçi öğrenme & 200 & 2.74 & 1.21 \\
Mühendislik temelli öğrenme & 200 & 2.69 & 1.19 \\
Lego ile öğrenme & 200 & 2.67 & 1.25 \\
Origami ile öğrenme & 200 & 2.59 & 1.37 \\
STEM eğitimi & 200 & 2.54 & 1.23 \\
Otantik öğrenme & 200 & 2.47 & 1.32 \\
Assure model & 200 & 2.16 & 1.14 \\
Bulut bilişim tabanlı öğrenme & 200 & 2.09 & 1.16 \\
Renzulli öğrenme & 200 & 1.81 & 1.13 \\
\hline
\end{tabular}

Tablo 5 incelendiğinde etkinlik temelli öğrenme yönteminin fen bilimleri öğretmenleri tarafından çok iyi düzeyde; sorgulamaya dayalı öğrenme, işbirlikli öğrenme, yaşam temelli öğrenme, oyun tabanlı öğrenme, yansitıcı öğrenme, altı şapkalı düşünme tekniği ve kavram karikatürü tekniğinin iyi düzeyde; kişiselleştirilmiş öğrenme, farklılaştırılmış öğretim, mobil öğrenme, senaryo temelli öğrenme, sokratik sorgulama tekniği, argümantasyon, çevrimiçi öğrenme, mühendislik temelli öğrenme, lego ile öğrenmenin orta düzeyde, origami ile öğrenme, STEM eğitimi, otantik öğrenme, assure model, bulut bilişim tabanlı öğrenme ve renzulli öğrenmenin ise düşük düzeyde bilindiği görülmektedir. Son y1llarda oldukça popüler olan STEM eğitimi yaklaşımının fen bilimleri öğretmenleri tarafından düşük düzeyde bilinmesi $(\bar{X}=2.54)$ dikkat çekici bir bulgu olarak karşımıza çıkmaktadır.

Fen bilimleri öğretmenlerinin her bir yeni yaklaşım, yöntem ve tekniği kullanma düzeyleri Tablo 6'da verilmiştir. 
Fen Bilimleri Öğretmenlerinin Yeni Yaklaşım, Yöntem ve Teknikleri Bilme ve Kullanma Düzeyleri ile Mesleki Tükenmişlikleri

Tablo 6. Fen Öğretiminde Yeni Yaklaşım, Yöntem ve Tekniklerin Fen Bilimleri Öğretmenleri Tarafından Kullanılma Düzeyleri

\begin{tabular}{cccc}
\hline Yaklaşım, Yöntem ve Teknikler & $\mathbf{N}$ & $\overline{\boldsymbol{X}}$ & $\mathbf{\text { ss }}$ \\
\hline Yaşam temelli öğrenme & 200 & 4.12 & 1.06 \\
Etkinlik temelli & 200 & 3.89 & 1.10 \\
Sorgulamaya dayalı öğrenme & 200 & 3.87 & 1.04 \\
İşbirlikli öğrenme & 200 & 3.73 & 0.93 \\
Oyun tabanlı öğrenme & 200 & 3.67 & 1.06 \\
Kavram karikatürü & 200 & 3.17 & 1.15 \\
Yansıtıcı Öğrenme & 200 & 3.15 & 1.12 \\
Kişiselleştirilmiş ögrenme & 200 & 2.94 & 1.20 \\
Altı şapkalı düşünme tekniği & 200 & 2.77 & 1.07 \\
Senaryo temelli & 200 & 2.76 & 1.21 \\
Farklılaştırılmış öğretim modeli & 200 & 2.70 & 1.27 \\
Mobil öğrenme & 200 & 2.58 & 1.31 \\
Sokratik sorgulama tekniği & 200 & 2.40 & 1.26 \\
Çevrimiçi öğrenme & 200 & 2.39 & 1.26 \\
Argümantasyon & 200 & 2.34 & 1.27 \\
Mühendislik temelli öğrenme & 200 & 2.25 & 1.17 \\
Lego ile öğrenme & 200 & 2.11 & 1.15 \\
Otantik öğrenme & 200 & 2.07 & 1.22 \\
STEM eğitimi & 200 & 2.01 & 1.21 \\
Origami ile öğrenme & 200 & 2.00 & 1.16 \\
Assure model & 200 & 1.89 & 1.21 \\
Bulut bilişim tabanlı öğrenme & 200 & 1.67 & 0.97 \\
Renzulli öğrenme & 200 & 1.49 & 0.90 \\
\hline
\end{tabular}

Tablo 6 incelendiğinde fen bilimleri öğretmenleri tarafından en çok kullanılan yaklaşım, yöntem ve tekniklerin sırasıyla yaşam temelli öğrenme, etkinlik temelli öğrenme, sorgulamaya dayalı öğrenme, işbirlikli öğrenme ve oyun tabanlı öğrenme olduğu görülmektedir. Tablo 5 ve 6 birlikte değerlendirildiğinde sıralamalarının farklı olmasıyla birlikte en çok bilinen ve uygulanan beş yöntem, yaklaşım veya tekniğin aynı olduğu göze çarpmaktadır. Fen bilimleri öğretmenleri en iyi düzeyde etkinlik temeli öğrenmeyi bildiklerini fakat en çok yaşam temelli öğrenmeyi kullandıklarını belirtmişlerdir. Fen bilimleri öğretmenleri kavram karikatürü, yansıtıcı öğrenme, kişiselleştirilmiş öğrenme, altı şapkalı düşünme tekniği, senaryo temelli öğrenme, farklılaştırılmış öğretim modeli, mobil öğrenme yaklaşım, yöntem ve tekniklerini orta sıklıkta kullandıkları bilgisini vermişlerdir. Altı şapkalı düşünme tekniği fen bilimleri öğretmenlerinin hakkında en çok bilgiye sahip olduğunu belirttikleri tekniklerden olmasına rağmen kullanma düzeyinin orta sıklıkta olması dikkat çekicidir. Renzulli öğrenme, bulut bilişim tabanlı öğrenme, Assure model, origami ile öğrenme, STEM eğitimi yaklaşımı, otantik öğrenme ise fen bilimleri öğretmenleri tarafından çok az kullanılan yaklaşım, yöntem ve tekniklerdir. Millî Eğitim Bakanlığının teşviklerine rağmen STEM yaklaşımının bilinme düzeyi gibi kullanım sıklığının da düşük seviyelerde olması şaşırtıcıdır. 
Fen bilimleri öğretmenlerinin yeni yaklaşım, yöntem ve teknikleri bilme ve kullanma düzeyleri arasındaki ilişkiyi belirlemek için; normallik, doğrusallık ve eş varyanslılık varsayımları yapılan ön analizlerle kontrol edilerek Pearson Momentler Çarpımı Korelasyon Analizi yapılmış ve sonuçlar Tablo 7'de verilmiştir.

Tablo 7. Fen Bilimleri Öğretmenlerin Yeni Yaklaşım, Yöntem ve Teknikleri Bilme Düzeyi ile Kullanma Düzeyi Arasındaki İlişkiye Ait Korelasyon Analizi Sonuçları

\begin{tabular}{ccc}
\hline & $\mathbf{1}$ & $\mathbf{2}$ \\
\hline 1.YYYTBD & 1 & 1 \\
2. YYYTKD & $.731^{*}$ & 2.65 \\
Ortalama & 3.12 & .61 \\
\hline Standart sapma & .68 & \\
\hline
\end{tabular}

Not: YYYTBD: Yeni Yaklaşım, Yöntem ve Teknikleri Bilme Düzeyi, YYYTKD: Yeni Yaklaşım, Yöntem ve Teknikleri Kullanma Düzeyi'ni simgelemektedir. ${ }^{*} p<.001$

Tablo 7 incelendiğinde yeni yaklaşım, yöntem ve teknikleri bilme düzeyi ile kullanma düzeyi arasında pozitif yönde yüksek düzeyde $(\mathrm{r}=.73, \mathrm{n}=200, \mathrm{p}<.001)$ ilişki olduğu görülmektedir. Yeni yaklaşım, yöntem ve teknikleri bilme ve kullanma düzeylerinin ne kadarlık varyansı paylaştı̆ı̆ın belirlemek için belirleme kat sayısı hesaplanmıştır $\left(\mathrm{r}^{2}=.53\right)$. Bu değer \% $\% 3$ ' lük ortaklaşa varyanstan bahsetmemize olanak sağlamaktadır. Bu bulgu yeni yaklaşım, yöntem ve teknikleri bilme düzeyi arttıkça kullanma düzeyinin de anlamlı olarak arttı̆̆ını göstermektedir.

Fen bilimleri öğretmenlerinin mesleki tükenmişlik düzeylerine ilişkin bulgular Tablo 8 'de sunulmuştur.

Tablo 8. Fen Bilimleri Öğretmenlerinin Mesleki Tükenmişlik Düzeylerine İlişkin Bulgular

\begin{tabular}{ccccc}
\hline & $\overline{\boldsymbol{X}}$ & ss & Min & Max \\
\hline Duygusal Tükenme & 3.19 & .31 & 2.44 & 4.00 \\
Duyarsızlaşma & 3.21 & .38 & 2.21 & 4.01 \\
Kişisel Başarı & 2.84 & .36 & 1.88 & 3.63 \\
\hline
\end{tabular}

Fen bilimleri öğretmenlerin tükenmişlik düzeyleri üç alt boyutta incelenmiştir. Duygusal tükenme ortalaması 3,19 olarak belirlenirken duyarsızlaşma ortalaması 3,20 ve kişisel başarı ortalaması ise 2,84 olarak tespit edilmiştir. Anket sonucunda üç alt boyutta elde edilen ortalamaların Maslach değerlendirme tablosunda (Tablo 2) yorumlanabilmesi için her bir ortalama alt boyutta yer alan soru adedi ile çarpılmıştır ve Tablo 9'daki sonuçlar elde edilmiştir.

Tablo 9. Tükenmişlik Alt Boyutlarındaki Genel Toplam Ortalamalar

\begin{tabular}{cccc}
\hline Alt Boyutlar & Ortalama & $\begin{array}{c}\text { Alt Boyutta Yer Alan } \\
\text { Soru Adedi }\end{array}$ & $\begin{array}{c}\text { Genel Toplam } \\
\text { Ortalama }\end{array}$ \\
\hline Duygusal Tükenme & 3.19 & 9 & 28.71 \\
Duyarsizlaşma & 3.21 & 5 & 16.05 \\
Kişisel Başarı & 2.84 & 8 & 22.72 \\
\hline
\end{tabular}


Fen Bilimleri Öğretmenlerinin Yeni Yaklaşım, Yöntem ve Teknikleri Bilme ve Kullanma Düzeyleri ile Mesleki Tükenmişlikleri

Fen bilimleri öğretmenlerinin üç alt boyutta tükenmişlik düzeylerini yorumlamak için MTE-EF puan değerlendirme tablosu (Tablo 2) kullanılmışır (Deran ve Beller, 2015: 80).

Fen bilimleri öğretmenlerinin duygusal tükenme ortalamaları 28,71 olarak hesaplanmış ve öğretmenlerin duygusal tükenme açısından yüksek düzeyde tükenmişlik gösterdikleri belirlenmiştir. Duyarsızlaşma alt boyutunda fen bilimleri öğretmenlerinin ortalaması 16,05 olarak hesaplanmış ve öğretmenlerin duyarsızlaşma açısından yine yüksek düzeyde tükenmiş̧lik gösterdikleri belirlenmiştir. Olumlu soruların yer aldığ 1 kişisel başarı alt boyutunda ise öğretmenlerin ortalaması 22,72 olarak belirlenmiş ve öğretmenlerin kişisel başarı boyutunda da oldukça tükenmiş ve karamsar oldukları sonucuna ulaşılmıştır.

Fen bilimleri öğretmenlerinin MTE-EF alt boyut düzeyleri ile yeni yaklaşım, yöntem ve teknikleri bilme ve kullanma düzeyleri arasındaki ilişkileri ve bu ilişkilerin büyüklük ve yönlerini bulmak için Pearson Momentler Çarpımı Korelasyon Analizi yapılmış ve sonuçlar Tablo 10'da sunulmuştur. Pearson Momentler Çarpımı Korelasyon Analizi için normallik, doğrusallık ve eş varyanslılık varsayımları yapılan ön analizlerle kontrol edilmiştir.

Tablo 10. Fen Bilimleri Öğretmenlerinin Mesleki Tükenmişlik Düzeyi ile Yeni Yaklaşım, Yöntem ve Teknikleri Bilme ve Kullanma Düzeyi Arasındaki İlişkilere Dair Korelasyon Analizi Sonuçları

\begin{tabular}{ccc} 
& YYYTBD & YYYTKD \\
\hline MTE-EF(DT) & -.094 & -.114 \\
MTE-EF (D) & .036 & .016 \\
MTE-EF (KB) & .135 & -.010 \\
\hline
\end{tabular}

Not: YYYTBD: Yeni Yaklaşım, Yöntem ve Teknikleri Bilme Düzeyi, YYYTKD: Yeni Yaklaşım, Yöntem ve Teknikleri Kullanma Düzeyi, MTE-EF(DT): Maslach Tükenmişlik Envanteri- Eğitimci Formu (Duygusal Tükenme), MTE-EF(D): Maslach Tükenmişlik Envanteri-Eğitimci Formu (Duyarsızlaşma), MTE-EF(KB): Maslach Tükenmişlik Envanteri- Eğitimci Formu (Kişisel Başarı)'yı simgelemektedir. $* p<.001$

Tablo 10 incelendiğinde fen bilimleri öğretmenlerinin yeni yaklaşım, yöntem ve teknikleri bilme ve kullanma düzeyleri ile MTE-EF alt boyut düzeyleri arasında istatistiksel olarak anlamlı bir ilişki bulunmadığı görülmektedir.

\section{Sonuçlar ve Tartışma}

Erzurum ili merkez ilçelerinde görev yapan fen bilimleri öğretmenlerinin fen öğretimindeki yeni yaklaşım, yöntem ve teknikleri bilme ve kullanma düzeylerini ve mesleki tükenmişliklerini belirlemek ayrıca aralarındaki ilişkiyi incelemek amacıyla yapılan bu çalışmada aşağıdaki sonuçlara ulaşılmıştır: 
- Fen bilimleri öğretmenlerinin genel olarak yeni yaklaşım, yöntem ve teknikleri orta düzeyde bildikleri ve orta sıklıkla kullandıkları sonucuna ulaşılmıştır. Fakat kullanma sıklığının düşük düzeye oldukça yakın olduğu göze çarpmaktadır. Buradan hareketle fen bilimleri öğretmenlerinin yeni yaklaşım, yöntem ve teknikleri bilme düzeylerinin kullanma düzeylerinden yüksek olduğu, yani nispeten fazla bilinen yaklaşım, yöntem ve tekniklerin bile öğrenme sürecinde yeterince kullanılmadığı sonucuna ulaşılmıştır.

Fen bilimleri öğretmenlerinin en çok etkinlik temelli öğrenme yaklaşımını bildikleri; bunu sorgulamaya dayalı öğrenme, işbirlikli öğrenme, yaşam temelli öğrenme, oyun tabanlı öğrenme, altı şapkalı düşünme tekniği, kavram karikatürü ve yansitıcı öğrenmenin izlediği görülmüştür. En az bilinen yaklaşım, yöntem ve tekniklere bakıldığında ise renzulli öğrenme, bulut bilişim tabanlı öğrenme, Assure model, otantik öğrenme ve STEM eğitimi yaklaşımı karşımıza çıkmaktadır. En dikkat çekici sonuç; dünyada artık yaygın hale gelen, ülkemizde de gittikçe yaygınlaştırılmaya çalışılan STEM eğitimi yaklaşımının fen bilimleri öğretmenleri tarafından beklenildiği düzeyde bilinmediği gerçeğidir. Ülkemizde 2016 yılında STEM eğitimi için bir eylem planı oluşturulmuş ve öğretmenlerin STEM eğitimi yaklaşımını benimseyecek şekilde yetiştirilmesinin gerekliliği vurgulanmıştır (MEB, 2016). Daha sonra fen bilimleri dersi öğretim programı güncellenerek, "Fen ve Mühendislik Uygulamaları" ünitesi 4. sınıftan 12. sınıfa kadar farklı ders saatlerinde programa, "Mühendislik ve Tasarım Becerileri" ise programın beceri öğrenme alanına eklenmiş ayrıca Fen-Teknoloji-Toplum-Çevre (FTTÇ) öğrenme alanı Fen-Mühendislik-Teknoloji-Toplum-Çevre (FMTTÇ) şeklinde değiştirilmiştir (MEB, 2017). Milli Eğitim Bakanlığı'nın 2018 yılında yaptığı bir değişiklikle "Fen ve Mühendislik Uygulamaları" ünitesi kaldırılmış yerine "Fen, Mühendislik ve Girişimcilik Uygulamaları" ünitesi getirilmiştir (MEB, 2018:25). MEB'in üzerinde bu kadar yoğunlaştı̆̆ bir yaklaşımın fen bilimleri öğretmenleri tarafindan en az bilinen yaklaşımlardan biri olması düşündürücü bir sonuçtur. Araştırmanın bir sınırlılı̆̆ olarak öğretmenlerle görüşme yapılmaması bu sonucun nedenini açılamakta yetersiz kalınmasına yol açsa da alan yazından yola çıkılarak bazı çıkarımlarda bulunmak mümkün gözükmektedir. Fen Bilimleri öğretmenlerinin üniversitelerden yeni yaklaşım, yöntem ve teknikleri yeterince öğrenmeden mezun olmaları, yetersiz hizmet içi eğitim almaları, lisans sonrası eğitime devam etmiyor oluşları, kendini geliştiren ve yenilikleri takip eden öğretmenlerin motivasyonunu artıran teşviklerin olmaması bu sonucun muhtemel nedenleri arasında görülmektedir (Çelikten, Şanal ve Yeni, 2005: 229; Çevik, Danıştay ve Yağc1, 2017; Çiftçi ve Çınar, 2017; Gülgün, Yılmaz ve Çağlar 2017, Özoğlu, 2010; Özyürek, 2008; Yıldırım, Öntaş ve Egüz 2018).

- Araştırma bulguları fen bilimleri öğretmenlerinin sınıf ortamında en fazla yaşam temelli öğrenme, etkinlik temelli öğrenme, sorgulamaya dayalı öğrenme, işbirlikli öğrenme ve oyun tabanlı öğrenmeyi kullandıklarını göstermektedir. Ayrıca fen bilimleri öğretmenlerinin renzulli öğrenme ve bulut bilişim tabanlı öğrenmeyi neredeyse hiç kullanmazken, sokratik sorgulama, çevrimiçi öğrenme, argümantasyon, mühendislik temelli öğrenme, lego ile öğrenme, otantik öğrenme, STEM eğitimi, origami ile öğrenmeyi ise oldukça düşük düzeyde kullanmayı tercih ettikleri sonucuna ulaşılmıştır. 
Fen Bilimleri Öğretmenlerinin Yeni Yaklaşım, Yöntem ve Teknikleri Bilme ve Kullanma Düzeyleri ile Mesleki Tükenmişlikleri

Bilme düzeylerinde son sıralarda yer alan STEM eğitimi yaklaşımının kullanma düzeylerinde de son sıralarda bulunması, yine çarpıcı fakat beklenen bir sonuç olarak karşımıza çıkmaktadır. Dünya ülkelerinde olduğu gibi ülkemiz tarafından da bir eğitim politikası olarak oldukça önemsenen STEM eğitimi yaklaşımının, popülerliği çok daha düşük olan yöntem ve yaklaşımlar kadar az biliniyor ve kullanılıyor oluşu üzerinde durulması gereken bir sonuç olarak değerlendirilmektedir.

- Araştırmanın sonucunda fen bilimleri öğretmenlerinin yeni yaklaşım, yöntem ve teknikleri bilme ve kullanma düzeyleri arasında pozitif yönde ve istatistiksel olarak anlamlı bir ilişki bulunmuştur. Yani yeni yaklaşım, yöntem ve teknikleri bilen öğretmenlerin aynı zamanda onları kullandıkları sonucuna ulaşılmıştır. Araştırmada fen bilimleri öğretmenleri tarafindan en çok bilinen beş yeni yaklaşım, yöntem ve tekniğin en çok kullanılan yaklaşım yöntem ve teknikle aynı olduğu sadece sıralamada farklılık olduğu görülmüştür. Ayrıca hemen her yaklaşım, yöntem ve teknik için bilinme düzeyinin kullanılma düzeyinden daha yüksek olduğu ortalamalar ile gözler önüne serilmiştir. Bu bulgudan yola çıkılarak fen bilimleri öğretmelerinin bildikleri yaklaşım, yöntem ve teknikleri bile öğrenme ortamında tam anlamıla uygulama firsatı bulamadıkları sonucuna varılmıştır. Bu sonuç çalışma verilerinin toplandığı fen bilimleri öğretmenlerinin mesleki deneyim, hizmet içi eğitim alma durumu ve görev yaptıkları okullarla ilgili verdikleri bilgiler (Tablo 1) göz önünde bulundurularak değerlendirilmeye çalışılmıştır. Verilerin toplandığı okulların oldukça büyük oranlarda fen laboratuvarı ve internet altyapısına sahip olması, öğretmenlerin yarısından fazlasının görev yaptı̆̆ okulun sosyo-ekonomik durumunu orta veya iyi olarak değerlendirmesi, yeni yaklaşım yöntem veya tekniklerin nispeten az uygulanmasının okulların fiziksel imkanlarıyla ilgili olmadığını göstermektedir. Fen bilimleri öğretmenlerinin büyük çoğunluğunun on yıldan az deneyime sahip olması veya yeni yaklaşım, yöntem ve teknikler ile ilgili hizmet içi eğitim almış olması gerek ögretmen yetiştiren fakültelerin gerekse hizmet içi eğitimlerin öğretmenlerin bilgi düzeylerini artırdığı fakat uygulamaya dönük daha az katkı sağladığı fikrini oluşturmaktadır. Nitekim alan yazında öğretmen adaylarının ileride kullanmak istedikleri yöntem ve teknikleri (Güven, Güç ve Özmen, 2016; Kubat, 2016) ve hizmet içi eğitimin etkinliğini (Özavcı ve Çelikten; 2017; Özbek, Susam, Onat, ve Özbek; 2018; Uzunöz, 2012) belirlemeye yönelik çalışmaların bu fikri destekler nitelikte olduğu görülmektedir.

$\mathrm{Bu}$ araştırma ile fen bilimleri öğretmenlerinin MTE-EF'na ait alt boyutlar olan duygusal tükenme, duyarsızlaşma ve kişisel başarı boyutlarının hepsinde yüksek tükenmişlik seviyesinde oldukları tespit edilmiştir. Bu sonuç Kayabaşı ve Cemaloğlu (2007)'nun araştırma sonuçları ile uyum gösterirken, alan yazında öğretmenlerin düşük mesleki tükenmişlik gösterdikleri sonucuna ulaşmış çalışmalara da rastlamak mümkündür (Cerit, 2008; Törnük, 2019; Türkçapar, 2011). Duygusal tükenme boyutunda yüksek tükenmişlik puanı duygusal olarak tükenmiş, ertesi gün çalıştığı kuruma dahi gitmekten hoşlanmayan; görevlerini yerine getirmek istemeyen, çokça izin alan, çalıştı̆̆ ortamdan uzaklaşabilmek adına bahaneler üreten bir öğretmen profilini karşımıza çıkarmaktadır (Çankıran, 2019; Sönmezgil, 2018). Duyarsızlaşma boyutundaki yüksek puan, çalıştığı kurumdaki kişilerden uzaklaşan ve umursamaz bir öğretmen demekken bu durum bireyi mesleki olarak yetersiz ve eksik hissetme 
durumuna düşürmektedir (Akten, 2007; Yiğit, 2007). Araştırmada yüksek tükenmişlik düzeylerinin nedeniyle ilgili bir bulgu olmamakla beraber alan yazında mesleki olarak kendini yetersiz hissetme, ilgisiz öğrenci profili, yönetimle yaşanan sorunlar, bürokrasi, istemsiz tayin durumları, memnuniyetsiz veli profili, problemli öğrenci davranışları, öğrencilerdeki motivasyon eksikliği öğretmenlerde tükenmişlik oluşturan etmenler olarak sıralanmaktadır (Erdemoğlu Şahin, 2007; Girgin ve Baysal; 2005, Russel, Altmaier ve Van Velzen, 1987, akt. Çankıran, 2019, Lopez; 2010). Öğretmenlerde yaşanan tükenmişlik duygusu bireysel olarak öğretmenin mesleki gelişimin yanında eğitim-öğretim sürecinin diğer paydaşları olan öğrenci, veli ve yöneticileri de doğrudan ilgilendirmektedir. Ayrıca öğretim sürecinin kalitesini de düşürmektedir (Harmsen, Helms-Lorenz, Maulana ve van Veen, 2018). Dolayısıyla öğretmenlerde belirlenen tükenmişliğin muhtemelen sebeplerinin tespit edilmesi, giderilmesi ve oluşumunun engellenmesi yönünde araştırmalar yapılması oldukça önemlidir (Durak ve Seferoğlu, 2017; Friedman ve Farber,1992; Kılınç, 2018). Tariş ve ark. (2017), tükenmişliği önlemenin tersine çevirmeye çalışmaktan çok daha kolay ve tercih edilmesi gereken bir yaklaşım olduğunu belirtmişlerdir.

- Son olarak araştırmada fen bilimleri öğretmenlerinin yeni yaklaşım, yöntem ve teknikleri bilme ve kullanma düzeyleri ile MTE-EF alt boyut düzeyleri arasında anlamlı bir ilişki olmadığı sonucuna ulaşılmıştır. Tükenmişlik kavramı doğası gereği öğretmenlerin öğretim sürecindeki performanslarını ve yenilikçi öğretim etkinliklerini uygulamalarını negatif olarak etkileyebilmektedir (Hoyos ve Kallus, 2005). Bu çalışmada ise öğretmenlerin tükenme, duyarsızlaşma ve kişisel başarı boyutlarının hepsinde yüksek tükenmişlik göstermelerine rağmen yeni yaklaşım yöntem ve teknikleri orta düzeyde bildikleri ve uyguladıkları sonucuna ulaşılmış ve yeni yaklaşım, yöntem ve teknikleri bilme ve kullanma düzeyleri ile MTE-EF alt boyut düzeyleri arasında ilişki olmadığı görülmüştür.

\section{VI. Öneriler}

Araştırma sonuçları bağlı olarak uygulamalara ve yeni araştırmalara yönelik öneriler aşağıda sunulmuştur:

- Milli Eğitim Bakanlığı’’nın öğretmenleri çağın gereksinimlerine uygun yöntem ve tekniklere yönelik hizmet içi eğitimlerin niteliğinin artırılması önerilebilir. Hizmet içi eğitimlerde teorik bilgi yanında uygulamalara ağırlık verilmesi, öğretmenlerin uygulama yapmasına firsat tanıyan ortamlar oluşturulmasına dikkat edilmelidir.

- Hizmet içi eğitimlerde özellikle eğitim programlarındaki değişikliklere adaptasyonu kolaylaştıracak içeriklerin artırılması da büyük önem arz etmektedir. Nitekim MEB'in üzerinde önemle durduğu ve programa dahil ettiğgi STEM eğitimi konusunda öğretmenlerin oldukça yetersiz olduğu sonucu bu öneriyi destekler niteliktedir. STEM eğitiminin uygulamaları ile ilgili öğretmenlere yardımcı olunmalı, gerekirse üniversite iş birliği sağlanarak akademisyenlerin öğretmenlere uzun süreli ve uygulamaya yönelik destek vermesi sağlanmalıdır.

- $\quad$ MEB tarafindan hazırlanan kılavuzlarda yeni yaklaşım, yöntem ve tekniklere uygulama örnekleri, örnek ders planları ile birlikte yer verilmelidir. 
Fen Bilimleri Öğretmenlerinin Yeni Yaklaşım, Yöntem ve Teknikleri Bilme ve Kullanma Düzeyleri ile Mesleki Tükenmişlikleri

- Yeni yaklaşım, yöntem ve teknikler EBA (Eğitim Bilişim Ağı) uygulaması üzerinden çeşitli film, video ve animasyonlar ile öğretmenlere uygulamalı olarak gösterilmelidir. Böylece hizmet içi eğitimlere katılma fırsatı bulamayan öğretmenlerin de sürece katılması sağlanabilir.

- Eğitim fakültelerinin istenen niteliklere sahip öğretmenlerin yetiştirilebilmesi için, öğretmen yetiştirme programların bilimsel araştırma bulgularına dayalı olarak geliştirilmesi sağlanmalıdır. Öğretmen eğitiminde yeni yaklaşım, yöntem ve tekniklerin teorik bilgisi yanında mutlaka etkinlik ağırlıklı bir program oluşturulmalı ve öğretmen adaylarının uygulama yapmasına olanak sağlayacak ders sayısı arttırılmalıdır.

- Fen bilimleri öğretmenleri ile birebir görüşmeler yapılarak yeni yaklaşım, yöntem ve tekniklerin bilinmeme ve kullanılmama nedenleri daha derinlemesine ortaya çıkarılabilir.

- $\mathrm{Bu}$ araştırmada yer almayan yaklaşım, yöntem ve tekniklerin bilinme ve kullanılma düzeyleri ile ilgili farklı araştırmalar yapılabilir.

- Fen bilimleri öğretmenlerinde tespit edilen yüksek mesleki tükenmişliğin nedenleri ayrıntılı olarak araştırılarak; öğretmenlerdeki mesleki tükenmişliğin önüne geçilmeye çalışılabilir.

\section{Kaynaklar}

Akten, S. (2007). Rehber öğretmenlerin mesleki tükenmişlik düzeylerinin incelenmesi (Tez no. 240932) [Yüksek lisans tezi, Trakya Üniversitesi-Edirne]. Yükseköğretim Kurulu Ulusal Tez Merkezi.

Aydede, M.N., Çăglayan, Ç., Matyar, F., ve Gülnaz, O. (2006). Fen ve teknoloji öğretmenlerinin kullandıkları öğretim yöntem ve tekniklerine ilişkin görüşlerinin değerlendirilmesi. Çukurova Üniversitesi Eğitim Fakültesi Dergisi, 3(32), 24-33.

Aydeniz, M. (2017). Eğitim sistemimiz ve 21. yüzyıl hayalimiz: 2045 hedeflerine ilerlerken, Türkiye için STEM odaklı ekonomik bir yol haritası. University of Tennessee, Knoxville.

Betoret, F, D. (2009). Self-efficacy, school resources, job stressors and burnout among Spanish primary and secondary school teachers: a structural equation approach. Educational Psychology. 29(1), 45-68.

Bozan, M. A. (2018). Sinlf öğretmenlerinin STEM odaklı mesleki gelişim süreçleri: bir eylem araştırması (Tez no. 506186) [Yüksek lisans tezi, Eskişehir Osmangazi Üniversitesi-Eskişehir]. Yükseköğretim Kurulu Ulusal Tez Merkezi.

Büyüköztürk, Ş., Kılıç Çakmak, E., Erkan Akgün, Ö., Karadeniz Ş., ve Demirel F. (2017). Bilimsel araştırma yöntemleri (23. Bask1). Pegem Akademi.

Cerit, Y. (2008). Öğretmen kavramı ile ilgili metaforlara ilişkin öğrenci, öğretmen ve yöneticilerin görüşleri (Views of students, teachers and administrators on the metaphor related to the concept of teacher), Türk Ĕgitim Bilimleri Dergisi, 6(4) 693712. 
Chan, D. W. (2007). Burnout, self-efficacy, and successful intelligence among chinese prospective and in-service school teachers in Hong Kong. Educational Psychology, 27(1), 33-49.

Çankıran, S. (2019). Özel eğitim alanında çalışan öğretmenlerin mesleki tükenmişlik ve iş doyumlarının mesleki benlik saygısı ve bazı değişkenler açısından incelenmesi (Tez no. 555243) [Yüksek Lisans Tezi, Necmettin Erbakan Üniversitesi-Konya]. Yükseköğretim Kurulu Ulusal Tez Merkezi.

Çelikkaleli, Ö. (2011). Yetişkin eğitimcisi öğretmenlerin tükenmişlik ve mesleki yetkinliklerinin incelenmesi. Mehmet Akif Ersoy Üniversitesi Sosyal Bilimler Enstitüsü Dergisi, 3(4), 38-53.

Çelikkaya, T., ve Kuş, Z. (2009). Sosyal bilgiler öğretmenlerinin kullandıkları yöntem ve teknikler. Uludağ üniversitesi, Eğitim Fakültesi Dergisi,12 (2), 741-758.

Çelikten, M., Şanal, M., ve Yeni, Y. (2005). Öğretmenlik mesleği ve özellikleri. Erciyes Üniversitesi, Sosyal Bilimler Enstitüsü Dergisi, 19, 207-237.

Çevik, M., Daniştay, A., ve Yağci, A. (2017). Ortaokul Öğretmenlerinin FeTeMM (FenTeknoloji-MühendislikMatematik) Farkındalıklarının Farklı Değişkenlere Göre Değerlendirilmesi, Sakarya University Journal of Education, 7(3), 584-589.

Çiftçi, M., ve Çınar, S. (2017). Fen bilgisi öğretmenlerinin STEM eğitiminin fen bilimleri dersine entegrasyonu hakkındaki görüşleri. 7.Uluslararası Eğitimde Araştırmalar Kongresi, 296-300.

Demirkan, Ö., ve Saraçoğlu, G. (2016). Anadolu Lisesi öğretmenlerinin derslerde kullandıkları öğretim yöntem ve tekniklerine ilişkin görüşleri, The Journal of International Lingual, Social and Educational Sciences, 2(1).

Deran A., ve Beller, B. (2015). Muhasebe meslek mensuplarında tükenmişlik sendromu üzerine Giresun il merkezinde yapılan bir araştırma. Erciyes Üniversitesi I.İ.B.F. Dergisi, 45, 69-93.

Durak, H., ve Seferoğlu, S. S. (2017). Öğretmenlerde tükenmişlik duygusunun çeşitli değişkenler açısından incelenmesi. GEFAD, 37(2): 759-788

Durr, A. J. (2008). Identifying teacher capacities that may buffer against teacher burnout. [Doktora tezi, The Ohio State University, Ohio, ABD].

EARGED (Eğitimi Araştırma ve Geliştirme Dairesi Başkanlığı). (2011). MEB 21. yüzyıl öğrenci profili. EB EARGED.

Egyed, C. J., \& Short, R. J. (2006). Teacher self-efficacy, burnout, experience and decision to refer a disruptive student. School Psychology International, 27(4), 462474.

Ekici, G., Çıbık, A. S., ve Fettahlığlu, P. (2014). Biyoloji öz-yeterlik inancı ile öğretmenlik mesleğine yönelik öz-yeterlik inancının öğretmenlik mesleğine yönelik 
Fen Bilimleri Öğretmenlerinin Yeni Yaklaşım, Yöntem ve Teknikleri Bilme ve Kullanma Düzeyleri ile Mesleki Tükenmişlikleri

tutumu yordama gücü. Gazi Üniversitesi Gazi Eğitim Fakültesi Dergisi, 34(1), 2341.

Erdemoğlu-Şahin, D. (2007). Öğretmenlerin mesleki tükenmişlik düzeyleri (Tez no.190958) [Yüksek lisans tezi, Gazi Üniversitesi-Ankara]. Yükseköğretim Kurulu Ulusal Tez Merkezi.

Erten, P. (2019). Öğretmen adaylarının 21. yüzyıl becerileri yeterlilik algıları ve bu becerilerin kazandırılmasına yönelik görüşleri. Millı Eğitim, 49(227), (33-64).

Gaines, C. B. (2011). Perceived principal support and middle school teacher burnout. Yayımlanmamış doktora tezi, University of Tennessee, Knoxville, ABD.

Geçer, A., \& Özel, N. (2012). Elementary science and techology teachers' views about problems encountered in the instruction process. Educational Science: Theory \& Practice, 12(3), 2256-2261.

Girgin, G., ve Baysal, A. (2005). Tükenmişlik sendromuna bir örnek: zihinsel engelli ögrencilere eğitim veren ögretmenlerin mesleki tükenmişlik düzeyi. TSK Koruyucu Hekimlik Bülteni, 4(4), 172-187.

Gülgün, C., Yılmaz, A., ve Çağlar, A. (2017). Fen bilimleri dersinde uygulanan STEM etkinliklerinde bulunması gereken nitelikler hakkında öğretmen görüşleri. Journal of Current Research on Social Science, 7(1), 459-478.

Güneş, T., Dilek, N. Ş., Çelikoğlu, M., \& Demir, E. S. (2011). The using levels of the teaching methods and techniques by teachers. Procedia-Social and Behavioral Sciences, $15,1092-1096$

Güven, B., Güç, F. A., \& Özmen, Z. M. (2016). Problem types used in math lessons: the relationship between student achievement and teacher preferences. International Journal of Mathematical Education in Science and Technology, 47(6), 863-876.

Harmsen, R., Helms-Lorenz, M., Maulana, R., \& van Veen, K. (2018). The relationship between beginning teachers' stress causes, stress responses, teaching behaviour and attrition. Teachers and Teaching, 24(6), 626-643.

Hoyos, T., \& Kallus, K. W. (2005). Burnout risk factors: Stress-recovery-state and coping among teachers. Department of Psychology. University of Graz. Austria

İnce, B. N., ve Şahin A. E. (2015). Maslach tükenmişlik envanteri-eğitimci formu'nu Türkçeye uyarlama çalışması. Eğitimde ve Psikolojide Ölçme ve Değerlendirme Dergisi, 6(2), 385-399.

Juuti, K., Lavonen, J., Uitto, A., Byman, R., \& Meisalo, V. (2010). Science teaching methods preferred by grade 9 students in Finland. International Journal of Science and Mathematics Education, 8(4), 611-632

Karahan, Ş., ve Uyanık Balat, G. (2011). Özel eğitim okullarında çalışan eğitimcilerin özyeterlik algılarının ve tükenmişlik düzeylerinin incelenmesi. Pamukkale Üniversitesi Eğitim Fakültesi Dergisi, 29(1), 1-14. 
Karasar, N. (2013). Bilimsel araştırma yöntemi (25.baskı). Nobel.

Kayabaşı, Y., ve Cemaloğlu, N. (2007). Öğretmenlerin sınıflarında kullandıkları disiplin modellerinin farklı değişkenler açısından incelenmesi. Kırşehir Eğitim Fakültesi Dergisi, 8, 149-170.

Kılınç, B. (2018). Fen Bilimleri Öğretmenlerinin Mesleki Tükenmişlik Düzeylerinin Bazı Değişkenler Açısından İncelenmesi, Fırat Üniversitesi Eğitim Bilimleri Enstitüsü (Yüksek Lisans Tezi), Elazı ğ.

Kokkinos, C. M. (2007). Job Stressors, Personality and Burnout in Primary School Teachers. British Journal of Educational Psychology, 77, 229-243. http://dx.doi.org/10.1348/000709905X90344

Kubat, U. (2016). Fen bilimleri öğretmenlerinin kullandıkları ölçme değerlendirme araçlarının değerlendirilmesi. Akademik Sosyal Araştırmalar Dergisi, 4(37), 449-460

Lopez, J. M. O., Bolano, C. C., Marino M. J. S., \& Pol, E. V. (2010). Exploring stress, burnout, and job dissatisfaction in secondary school teachers. International Journal of Psychology and Psychological Therapy, 10(1), 107-123.

Maslach, C., \& Jackson, S. E. (1981). The measurement of experienced burnout. Journal of Occupational Behavior, 2(1), 99-113.

Maslach, C., Schaufeli, W. B., \& Leither, M.P. (2001). Job burnout. Annual Review of Psychology, 52, 397-422.

MEB (2016). STEM eğitimi raporu. Ankara: Yenilik ve Eğitim Teknolojileri Genel Müdürlüğ̈̈. https://yegitek.meb.gov.tr/STEM_Egitimi_Raporu.pdf adresinden edinilmiştir.

MEB (2018). Fen bilimleri dersi öğretim programı (illkokul ve ortaokul 3, 4, 5, 6, 7, ve 8. Sinıflar). Devlet Kitapları Müdürlüğü Basımevi.

Mihladiz, G., \& Duran, M. (2013). Views of elementary education students related to science and technology teaching process. Social and Behavioral Sciences, 141, 290 $-297$.

OECD (2005a). Teachers Matter: Attracting, Developing and Retaining Effective Teachers.

OECD (2005b). Formative Assesment: Improving learning in Secondary Classrooms.

Önen, F., Mertoğlu, H., Saka, M., \& Gürdal, A. (2009). Hizmet içi eğitimin öğretmenlerin öğretim yöntem ve tekniklerine ilişkin bilgilerine etkisi. Ahi Evran Üniversitesi Ĕ̈itim Fakültesi Dergisi, 10(3), 9-23.

Özavcı E., \& Çelikten M. (2017). Öğretmen görüşlerine göre uzaktan hizmet içi eğitim uygulamalarında karşılaşılan sorunlar ve çözüm. Turkish Journal of Educational Studies, 4(2), 39-76. 
Fen Bilimleri Öğretmenlerinin Yeni Yaklaşım, Yöntem ve Teknikleri Bilme ve Kullanma Düzeyleri ile Mesleki Tükenmişlikleri

Özbek, R., Susam, E., Onat, M., C., ve Özbek, N. (2018). Ortaokul öğretmenlerinin MEB hizmet içi eğitim programlarının etkililiğine ve bu faaliyetlerin yapıldığı yerlere ilişkin görüşleri (Siirt ili örneği). The Journal of International Lingual Social and Educational Sciences, 4(2), 126-134

Özoğlu, M. (2010). Türkiye'de öğretmen yetiştirme sisteminin sorunları. Siyaset, Ekonomi ve Toplum Araştırmaları Vakfi, 17.

Özyürek, M. (2008). Nitelikli öğretmen yetiştirmede sorunlar ve çözümler: Özel eğitim örneği. Türk Ĕgitim Bilimleri Dergisi, 6 (2), 189-226.

Pedro, F. (2006). The New Millennium Learners: Challenging our Views on ICT and Learning.

Seçer, İ. (2015). Üniversite öğrencilerinde okul tükenmişliği ile psikolojik uyumsuzluk arasındaki ilişkinin incelenmesi. Atatürk Üniversitesi Sosyal Bilimler Enstitüsü Dergisi, 19(1): 81-99

Seferoğlu, S. S., Yıldız H., ve Yücel Avcı, Ü. (2014). Öğretmenlerde Tükenmişlik: Tükenmişliğin Göstergeleri ve $\mathrm{Bu}$ Göstergelerin Çeşitli Değişkenler Açısından İncelenmesi, Eğitim ve Bilim, 39(174), 348-364.

Soylu, Y. (2009). Sınıf öğretmen adaylarının matematik derslerinde öğretim yöntem ve teknikleri kullanabilme konusundaki yeterlilikleri üzerine bir çalışma. Mersin Üniversitesi Ĕgitim Fakültesi Dergisi, 5(1), 1-16.

Sönmezgil, C. A. (2018). Mesleki tükenmişliğin psikopatoloji, inanç ve kontrol odă̆ yönünden değgerlendirilmesi, Yüksek Lisans Tezi, Işık Üniversitesi Sosyal Bilimler Enstitüsü, İstanbul.

Sözbilir, M., Şenocak, E., ve Dilber, R., (2006). Öğrenci gözüyle fen bilgisi öğretmenlerinin derslerinde kullandıkları öğretim yöntem ve teknikleri. Milli Eğitim Dergisi, 172, 276-286.

Şimşek, H., ve Coşkun, M. (2012). İlköğretim fen ve teknoloji öğretmenlerinin öğretim yöntem ve tekniklerini tercih ve uygulama düzeyleri: Şanlıurfa ili örneği. Mustafa Kemal Üniversitesi Sosyal Bilimler Enstitüsü Dergisi, 9(18), 249-268.

Tabachnick, B. G., \& Fidell, L. S. (2013). Using multivariate statistics (6th ed.), Allyn and Bacon.

Taris, T., Leisink, P., \& Schaufeli, W. (2017). Applying occupational health theories to educator stress: Contributions of the jobs-demands resources model (pp. 237-260). In T. McIntyre, S. McIntyre, and D. Francis (Eds), Educator Stress: An Occupational Health Perspective. Huston, TX: Springer. https://doi.org/10.1007/978-3-319-53053$6 \_11$

Tekbıyı, A. (2014). İlişkisel tarama (M. Metin, Ed.). Kuramdan uygulamaya eğitimde bilimsel araştırma yöntemleri. Pegem A.

Tekin, H. (1993). Eğitimde Ölçme ve Değerlendirme. Yargı Yayıncılık. 
Timur, B., ve İmer, N. (2012). Fen ve teknoloji öğretmenlerinin derste kullandıkları öğretim yöntem ve tekniklerinin incelenmesi. X. Ulusal Fen Bilimleri ve Matematik Eğitimi Kongresi. Niğde Üniversitesi, Eğitim Fakültesi tarafindan düzenlenen kongre, Niğde.

Törnük, N. (2019). Okul öncesi öğretmenlerinin tükenmişlik düzeylerinin yordayıcısı olarak mesleki sosyal destek algısı. Yüksek lisans tezi, Sosyal Bilimler Enstitüsü, İstanbul Sabahattin Zaim Üniversitesi, İstanbul.

Troman, G., \& Woods, P. (2000). Careers under stress: Teacher adaptations at a time of intensive reform. Journal of Educational Change, 1, 253-275.

Türkçapar, Ü. (2011). Beden eğitimi öğretmenlerinin farklı değişkenlere göre tükenmişlik düzeylerinin incelenmesi. Türkiye Sosyal Araştırmalar Dergisi, 15(3), 135-146.

Uzunöz, Y., A., A. (2012). Trabzon'da görev yapmakta olan coğrafya öğretmenlerinin hizmetiçi eğitim faaliyetlerinin yeterliliği ile ilgili düşünceleri. Karadeniz Incelemeleri Dergisi, 12(12), 189-202.

Williams, J. H. \& Engel, L. C. (2012/2013). How do other countries evaluate teachers? Kappan. 94(4). 53-58

Yarım, M., ve Çelik, S. (2020). Endüstri 4.0 çağında öğrenci gözüyle öğretmenin gerekliliği ve rolü. Mehmet Akif Ersoy Üniversitesi Sosyal Bilimler Enstitüsü Dergisi, (31), 76-92. DOI: 10.20875/makusobed.541669

Yıldırım, Z., ve Demir, K. (2003). Burdur il merkezindeki ilköğretim okullarında görev yapan fen bilgisi öğretmenlerinin alanları ve yeterliliklerine ilişkin görüşleri ile fen bilgisi eğitimi öğrencilerinin bu öğretmenler ile ilgili gözlemleri. Sakarya Üniversitesi Ĕ̈itim Fakültesi Dergisi, 4, 134-145.

Yıldırım, E., Öntaş, T., \& Egüz, Ş. (2018). An investigation into the relationship between citizenship perceptions, political contributions and political interests of primary and social studies teachers. Karaelmas Journal of Educational Sciences, 6, 163-175.

Yiğit, A. (2007). Özel eğitim kurumlarında çalı̧san öğretmenlerin iş doyumu tükenmişlik ve ruh sağlık düzeylerinin çeşitli değiş̧kenler açısından incelenmesi (Tez no. 209320) [Yüksek lisans tezi, Niğde Üniversitesi-Niğde]. Yükseköğretim Kurulu Ulusal Tez Merkezi. 